\title{
Canned native-style concentrates for Puerto Rican-flavored rice dishes'
}

\author{
Isabel Beauchamp de Caloni $i^{2}$ and Teresita Rodriguez
}

\begin{abstract}
ABSTRACT

A simple standard method was developed for the preparation of native flavored rice dishes using canned concentrates as a base. Heat penetration studies were conducted at the pilot plant to prepare concentrates with chicken, codfish, pink beans, Vienna and pork sausages. The sterilization process for each concentrate was determined by graphic and numerical methods. Microbiological analyses for low acid canned producis proved them to be commercially sterile and thus marketable. A faste panel evaluated the rice dishes prepared with the concentrotes at 0,2 and 4 months storage. Appearance and flavor of the rice dishes were found acceptable up to 4 months of storage.
\end{abstract}

\section{RESUMEN}

Concentrados enlatados para platos a base de arroz con sabor típico puertorriqueño

Se desarrall6 un méfodo uniforme y sencillo para preparar platos de arroz con sabor típico a base de concentrados enlatados. Los estudios de penetración de calor se hicieron en la planta piloto de elaboración para el enlatado de concentrados con pollo, bacalao, habichuelas rosadas, salchichas y chorizo. Los procesos para esterilizar los concenfrados se determinaron mediante métodos numéricos y gráficos. Los análisis microbiológicos para productos enlatados de baja acidez demostraron la esterilidad comercial del producto. Un grupo de catadores evaluó los platos de arroz confeccionados con los concentrados a los 0,2 y 4 meses de almacenamiento. Todos los platos fueron aceptables durante todo el estudio en apariencia y sabor.

\section{INTRODUCTION}

The two major food cereals, rice and wheat, provide a large proportion of the total nourishment of the world's population (1). However, available information on rice is scattered, in contrast to that of wheat, which has been well researched and published.

Rice is grown in more than 100 countries on every continent of the world (except Antarctica) from north to south latitudes. It is the main staple food for one half to two thirds of the world population. It accounts for one half to one third of the caloric intake (7). Rice protein has one of

'Manuscript submitted to Editorial Board 25 March 1991. We express our gratitude to Luis Silva, Research Associate, and Irvis Pagan, Laboratory Technician I, for their assistance in the microbiological analyses of samples and in the pilot plant work, respectively.

${ }^{2}$ Food Technologist, Laboratory of Food Technology.

'Research Associate, Laboratory of Food Technology. 
the highest nutritive values among cereal proteins. Protein quality of rice can be enhanced with amino acid enrichment. By law, rice is enriched with vitamins and minerals in premix kernels added during processing (7).

Puerto Ricans, as well as people in other Caribbean islands, are great consumers of rice, which is prepared in a variety of stewed dishes mixed with meat, fish, poultry or vegetables. The preparation of such dishes is time consuming work. Pre-cooked rice products requiring minimum effort have been studied in other countries. Processes for the preparation of pre-cooked paella, rice flakes flavored with tropical fruit pulp, and extruded quick-cooking rice-like products are available $(4,8,9,10,13)$. In the Orient, the manufacture of rice snack foods such as crackers, cake, chocolate and chewing gum is a promising industry (7). Other rice products produced in China and Japan are flours, noodles, bran, wine and rice oil.

This research was done to determine the feasibility of canning native style concentrates to be used as a base for preparing popular Puerto Rican-flavored rice dishes in a simple standard way.

\section{MATERIALS AND METHODS}

We developed formulas for the elaboration of five concentrates to be used as a base for preparing native flavored rice dishes. The chicken concentrate had the following formulation per can ( $454 \mathrm{~g}$ ) of product:

\begin{tabular}{lrr} 
Ingredient & Weight $(g)$ & \%Weight \\
& & \\
Onion & 73.2 & 16.1 \\
Pepper & 18.3 & 4.0 \\
Garlic & 2.2 & 0.5 \\
Sweet peppers & 3.7 & 0.8 \\
Coriander & 0.7 & 0.2 \\
Marjoram & 0.5 & 0.1 \\
Vegetable oil & 4.1 & 0.9 \\
Tomato paste & 41.7 & 9.2 \\
Olives and capers & 25.6 & 5.6 \\
Water & 95.9 & 21.2 \\
Salt & 5.2 & 1.1 \\
Chicken pieces & $\underline{182.9}$ & 40.3 \\
\multicolumn{1}{r}{ Total } & 454.0 & 100.0
\end{tabular}

For chicken concentrate, skins were removed from chicken breasts, which were cut into 1 1/2-2-inch pieces $(36.6 \mathrm{~g})$. Onion, pepper, garlic cloves, sweet peppers and coriander were ground in an electric blender. The vegetables were cooked in hot oil in a steam jacket kettle (8 to 10 PSI) for 8 minutes. Tomato paste and prepared chicken pieces were 
added to the kettle along with the salt, marjoram, olives and capers and water. Chicken was cooked in the sauce (8 to 10 PSI) for 20 minutes until chicken pieces reached an internal temperature of $160^{\circ} \mathrm{F}$. Water was added to the kettle to compensate for evaporation. The concentrate was heated to $185^{\circ}$ to $190^{\circ} \mathrm{F}$.

C-type enameled $33 \times 406$ cans were filled with five pieces of chicken and enough concentrate to total $454 \mathrm{~g}(16 \mathrm{oz}$.).

Table 1 presents formulation per can ( $454 \mathrm{~g}$ ) of pink bean, pork sausage, Vienna sausage and codfish concentrates.

Codfish was desalted in boiling water for 3 minutes, after which time the water was discarded. Pink beans were soaked in tap water at room temperature to $100 \%$ weight and blanched at $190^{\circ} \mathrm{F}\left(87.8^{\circ} \mathrm{C}\right)$ for 3 minutes before canning. Vienna sausages (salchichas) were cut in pieces 0.5 inch thick and pork sausages (chorizo) in pieces 0.25 inch thick $\times 1$ inch diameter.

For the codfish, bean and sausage concentrates, vegetables were ground and cooked, and spices were added by the same method as for the chicken concentrate. To each $303 \times 406 \mathrm{C}$-enameled can, $150 \mathrm{~g}$ of beans, pork or Vienna sausage, or $160 \mathrm{~g}$ of codfish was added. Prepared concentrate was added to complete a total weight of $454 \mathrm{~g} \mathrm{(16} \mathrm{oz)} \mathrm{per} \mathrm{can.}$

After canning, concentrates were heat sterilized in a retort at $250^{\circ} \mathrm{F}$ $\left(121.1^{\circ} \mathrm{C}\right)$. Heat penetration was monitored with a Kaye Digi $4 \mathrm{M}$ System

TABLE 1.-Concentrate formulation per can $(454 \mathrm{~g})$ of product

\begin{tabular}{lcccc}
\hline Ingredient & $\begin{array}{c}\text { Beans or } \\
\text { sausages } \\
\text { weight (g) }\end{array}$ & Codfish & $\begin{array}{c}\text { Beans or } \\
\text { sausages } \\
\text { \% weight) }\end{array}$ & Codfish \\
\hline Onion & 84.5 & 81.7 & 18.6 & 17.9 \\
Peppers & 21.1 & 20.4 & 4.7 & 4.5 \\
Garlic & 2.5 & 2.44 & 0.6 & 0.5 \\
Sweet peppers & 4.2 & 4.1 & 0.9 & 0.9 \\
Coriander & 0.8 & 0.8 & 0.2 & 0.2 \\
Marjoram & 0.3 & 0.3 & 0.1 & 0.1 \\
Vegetable oil & 4.8 & 4.6 & 1.0 & 1.0 \\
Tomato paste & 48.1 & 46.6 & 10.6 & 10.3 \\
Olives and capers & 21.1 & 20.4 & 4.6 & 4.5 \\
Water & 110.6 & 106.9 & 24.4 & 23.6 \\
Salt & 6.0 & 5.8 & 1.3 & 1.3 \\
Pink beans or sausages & 150.0 & $\ldots .$. & 33.0 &..- \\
Codfish &..- & 160.0 &..- & 35.2 \\
\hline Total & 454.0 & 454.0 & 100.0 & 100.0 \\
\hline
\end{tabular}


(Bedford $\mathrm{Ma})^{4}$ to record temperature and time. Cold spot (slowest heating point inside the can) was determined with Ecklund t-type 19/16 inch molded plastic thermocouples placed at $3 / 4$ inch, 1 inch, $11 / 2$ inch and 2 $1 / 8$ inch measured from the bottom of the can.

To calculate the sterilization process, we chose a $Z$ value of 18 (the number of degrees Farenheit required for the thermal destruction curve to traverse one logarithmic cycle). The sterilization process in minutes ( $F$ value) and processing time were determined by the graphic (General method of Bigelow) and numerical (Patshnik) methods (2, 5, 11, 12).

Within five days of elaboration, we did microbiological analyses to detect organisms capable of growing in low acid canned foods. We used cooked meat medium and bromocresol purple broth tubes incubated at $35^{\circ} \mathrm{C}\left(95^{\circ} \mathrm{F}\right)$ and $55^{\circ} \mathrm{C}(131 . \mathrm{F})$ for 120 and 72 hours, respectively (3).

Flow diagram of processing steps in the canning of the five concentrates:

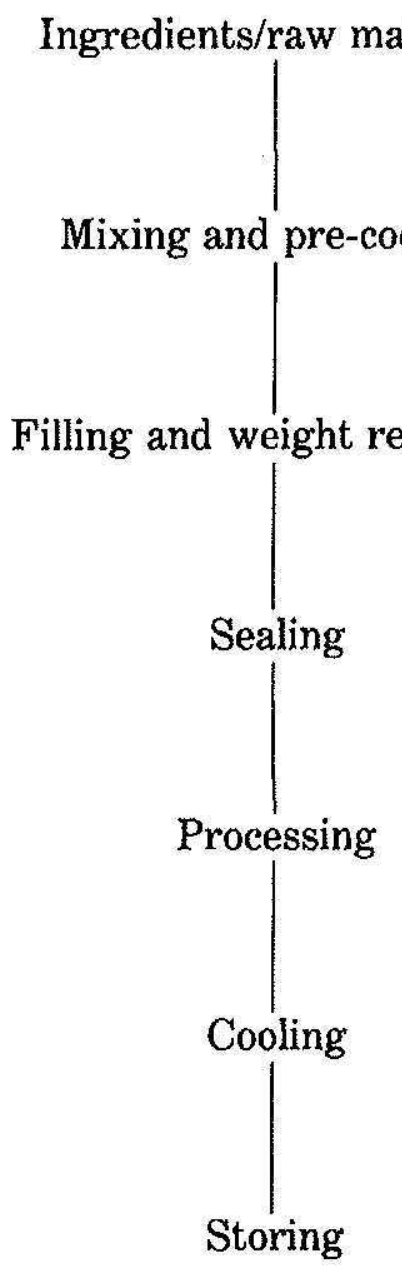

"Trade names in this publication a'e used only to provide specific information. Mention of trade names does not constitute a warranty of equipment or materials by the Agricultural Experiment Station of the University of Puerto Rico, nor is this mention a statement of preference over other equipment or materials. 
For sensory evaluation, rice dishes were prepared with $11 / 2$ cups rice and 1 1/2 cup water per can of concentrate. The concentrate was heated for a few minutes. Rice and water were added and mixed well. Rice was cooked on top of stove at medium heat until water was absorbed. Then it was covered and allowed to cook for an additional 20 to 25 minutes. The prepared rice dishes were sensory evaluated as to appearance and flavor by a taste panel using the $+2,-2$ scale $(+2=$ very acceptable; $-2=$ not acceptable) at 0,2 and 4 months storage (6).

\section{RESULTS AND DISCUSSION}

Table 2 shows the heat sterilization data of the five canned products. Net and drain weights, initial temperature, Fo values [number of minutes at $250^{\circ} \mathrm{F}\left(121^{\circ} \mathrm{C}\right)$ necessary to achieve commercial sterility] and total process time were calculated for each product. Cold spot of cans was determined at $21 / 8$ inches from the bottom of the can at the geometrical center. The data of the slowest heating can was used as the basis for estimating the Fo value and processing time. The Fo value of the products varied from 15.52 for the concentrate and sausages to 19.63 minutes for the concentrate and beans. Total processing time (minutes) ranged from 74.0 for the concentrate and sausage to 94.5 for the concentrate and codfish.

Sterilization processes suggested in this study are for these particular formulas and for experimental purposes only. Any changes in the formulas, size and shape of cans, fill-in weight or initial temperature of product may alter the thermal processes determined, thus affecting the safety and quality of the product. For any commercial production of these products, a thermal process to assure commercial sterility (a condition achieved by the application of heat necessary to destroy all viable forms of pathogenic microorganisms or of organisms capable of spoiling a product under non refrigerated storage condition) should be calculated

TABLE 2.-Heal sterilization data of five different products in $303 \times 406$ cans $^{\prime}$

\begin{tabular}{|c|c|c|c|c|c|}
\hline & Net weight & Drain weight & Initial temperature & Fo & $T p^{2}$ \\
\hline & $g$ & $g$ & ${ }^{\circ} \mathrm{F}$ & $\min$. & $\min$. \\
\hline Chicken & 464.60 & 224.20 & 174.50 & 19.41 & 84.0 \\
\hline Bean & 493.87 & 379.28 & 153.40 & 19.63 & 92.5 \\
\hline $\begin{array}{l}\text { Sausage } \\
\quad \text { (salchicha) }\end{array}$ & 430.67 & 227.28 & 184.20 & 15.62 & 74.0 \\
\hline $\begin{array}{l}\text { Sausage } \\
\text { (chorizo) }\end{array}$ & 460.56 & 219.94 & 175.50 & 18.24 & 90.0 \\
\hline Codfish & 481.88 & 363.08 & 134.50 & 17.30 & 94.5 \\
\hline
\end{tabular}

'Retort temperature: $250^{\circ} \mathrm{F}\left(121.1^{\circ} \mathrm{C}\right)$.

'Total process time. A $\mathrm{Z}$ value of 18 was assumed. 
TABLE 3.-Sensory evaluation of rice dishes prepared from concentrates

\begin{tabular}{lcccccccc}
\hline & \multicolumn{5}{c}{ Mean values' } \\
\cline { 2 - 8 } & \multicolumn{3}{c}{ Appearance } & & \multicolumn{3}{c}{ Flavor } \\
\hline Rice dish & $0^{2}$ & 2 & 4 & 0 & 2 & 4 \\
\hline Rice with chicken & 1.55 & 1.42 & 1.25 & 1.18 & 1.25 & 1.17 \\
Rice with pink beans & 1.60 & 1.40 & 0.70 & 1.30 & 1.20 & 0.90 \\
Rice with codfish & 1.58 & 1.30 & 1.13 & 1.42 & 0.90 & 1.00 \\
Rice with sausages (salchicha) & 1.00 & 1.22 & 1.22 & 1.00 & 1.11 & 1.00 \\
Rice with pork sausage (chorizo) & 1.25 & 1.60 & 1.33 & 1.00 & 1.40 & 1.67 \\
\hline
\end{tabular}

$1+2,-2$ scale; $+2=$ very acceptable; $-2=$ not acceptable.

${ }^{2} 0,2,4=$ months in storage.

by a processing authority recognized as such by the U.S. Food and Drug Administration.

Microbiological analyses (data not presented) showed that the products were free from organisms. Safety of the thermal processes given to the canned products was thus confirmed.

Table 3 presents the sensory evaluation of rice dishes prepared with the canned concentrates. All rice dishes were rated acceptable in appearance and flavor at 0-, 2- and 4- month evaluation. Rice with sausages (chorizo) and rice with chicken scored the highest in appearance and flavor when evaluated after 4 months storage of the concentrate.

\section{LITERATURE CITED}

1. American Association of Cereal Chemists, Inc. 1972. Rice-chemistry and technology. St. Paul, Minnesota.

2. American Can Company Technical Service, 1967. Calculation of process for canned foods. American Can Company. Barrington, Illinois.

3. Association of Official Analytical Chemists, 1984. Bacteriological Analytical Manual 6th ed., Div. of Microb. Center for Food Safety and Applied Nutrition, U. S. Food and Drug Administration.

4. Groesbeck, C. A., J. Hsu and G. Larson, 1989. Rice product. European Patent Appl. EPO 306655 AI. Nestle, S.A. Vevey, Switzerland.

5. I.F.T., 1978. Introduction to the fundamentals of thermal processing. Institute of Food Technologists. Chicago, Illinois.

6. Larmond, E., 1977. Laboratory methods for the sensory evaluation of food. Food Res. Inst. Canada Dep. of Agxic. Publ. 1637.

7. Luh, Bor S., 1980. Rice production and utilization. AVI Publ. Co., Inc. Westport, Conn.

8. Rivera, J., B. Molina and G. Pertz, 1986. Manufacture of rice flakes flavored with tropical fruit pulp. Boletin Tenico LABAL 7, Lab. Tec. Alim., Managua, Nicaragua.

9. Scelia, R. P., E. Hegedus, J. Giacone, H. B. Bruins and E. J. Benjamin, 1987. Extruded quick-cooking rice-like product. European Patent Appl. EPO 226375 AI Wh. Pl., N.Y.

10. Segura-Castao, J., 1989. Procedure for preparation of pre-cooked paella. European Patent Appl. EP0 300948 AI Barcelona, Spain. 
11. Stumbo, C. R., 1973. Thermobacteriology in food processing. 2nd ed., Academic Press, New York and London.

12. —_, K. S. Puroit, T. V. Ramakrishnan, D. A. Evans and F. J. Francis, 1983. "CRC Handbook of lethality guides for low-acid canned foods". CRC Press, Inc., Boca Ratón, Florida.

13. Zuckerman, H. W., R. B. Zuckerman, 1988. Process for making microwavable rice products. U.S. Patent 4764390 . Northbrook, Il. U.S.A. 